\title{
ARTI PENTING LEGAL REASONING BAGI HAKIM DALAM PENGAMBILAN PUTUSAN DI PENGADILAN UNTUK MENGHINDARI “ONVOLDOENDE GEMOTIVEERD”
}

\author{
Aditya Yuli Sulistyawan, Aldio Fahrezi Permana Atmaja \\ Fakultas Hukum Universitas Diponegoro, Semarang \\ adityayuli38@gmail.com
}

\begin{abstract}
Abstrak
Hakim adalah sebuah profesi yang mulia (officium nobile) yang diharapkan dapat mewujudkan keadilan dalam konteks penegakan hukum. Hakim menjatuhkan putusan sesuai dengan keyakinannya atas suatu kebenaran, sesuai dengan proses pemeriksaan perkara di muka pengadilan. Dalam memutus suatu perkara, hakim harus membangun penalaran yang memadai dalam bentuk pertimbangan-pertimbangan yang dinyatakan di dalam putusannya, hal mana disebut sebagai legal reasoning. Kegagalan membangun legal reasoning dapat berimplikasi pada suatu putusan dikategorikan sebagai Onvoldoende Gemotiveerd atau kurang pertimbangan hukum. Maka dari itu sangatlah penting seorang hakim untuk cermat dalam menganalisis perkara berdasarkan fakta, hukum yang berlaku, yurisprudensi serta pertimbangan lainnya sehingga mengasilkan suatu putusan yang memiliki argumentasi yang kuat dalam setiap keputusannya agar tidak menyimpang dari kaidah-kaidah hukum. Tujuan penulisan ini adalah untuk menunjukkan arti penting legal reasoning bagi hakim dalam pengambilan putusan di pengadilan untuk menghindari Onvoldoende Gemotiveerd. Hasil pembahasan menunjukkan legal reasoning dapat dilakukan oleh hakim dengan penemuan hukum melalui interpretasi hukum dan konstruksi hukum. Hal ini dapat dilakukan untuk melengkapi pertimbangan hakim dalam suatu putusan, bilamana suatu aturan hukum kurang jelas, tidak jelas, atau tidak lengkap. Dengan demikian, dapat disimpulkan bahwa suatu putusan hakim harus memadai dalam pertimbangannya sehingga harus dibangun dengan legal reasoning yang kuat, dasar hukum dan penalaran yang logis dan cermat sebagai landasan rasional atas putusan yang dijatuhkan.

Kata kunci: Hakim; Legal Reasoning; Onvoldoende Gemotiveerd; Putusan
\end{abstract}

\section{THE IMPORTANCE OF LEGAL REASONING FOR JUDGES IN MAKING DECISIONS IN COURT TO AVOID “ONVOLDOENDE GEMOTIVEERD”}

\begin{abstract}
Judge is a noble profession (officium nobile) which is expected to realize justice in the context of law enforcement. The judge makes a decision in accordance with his belief in truth, in accordance with the process of examining the case before the court. In deciding a case, the judge must develop adequate reasoning in the form of considerations stated in his decision, which is called legal reasoning. Failure to build legal reasoning can have implications for a decision categorized as Onvoldoende Gemotiveerd or lack of legal consideration. Therefore, it is very important for a judge to be careful in analyzing cases based on facts, applicable law, jurisprudence and other considerations so as to produce a decision that has strong arguments in every decision so as not to deviate from legal rules. The purpose of this paper is to show the importance of legal reasoning for judges in making decisions in court to avoid Onvoldoende Gemotiveerd. The results of the discussion show that legal reasoning can be carried out by judges by finding law through legal interpretation and legal construction. This can be done to complete the judge's consideration in a decision, if a legal rule is unclear, unclear, or incomplete. Thus, it can be concluded that a judge's decision must be adequate in its considerations so that it must be built with strong legal reasoning, legal basis and logical and careful reasoning as a rational basis for the decision handed down. Kata kunci: judge; legal reasoning; Onvoldoende Gemotiveerd; verdict
\end{abstract}




\section{PENDAHULUAN}

\section{A. Latar Belakang}

Dalam sistem peradilan di Indonesia hakim adalah penentu utama putusan dalam suatu perkara di pengadilan, berbeda dengan di negara Amerika Serikat yang mengadopsi sistem common law dari Inggris yang telah berevolusi dimana dalam prakteknya keputusan pengadilan juga didasarkan oleh keputusan juri yang merupakan sekelompok masyarakat umum yang ditunjuk secara acak dari masyarakat yang bertemu untuk menentukan apakah ada sebab yang cukup untuk percaya bahwa seseorang telah melakukan kejahatan federal yang didakwakan kepadanya.

Menurut Cik Hasan Bisri sebagaimana dikutip oleh Nur Iftitah Isnantiana, hakim secara etimologi berarti orang yang memutuskan hukum. ${ }^{1}$ Hakim merupakan unsur utama di dalam pengadilan. Bahkan ia identik dengan pengadilan itu sendiri. Dengan sistem peradilan di Indonesia hakim adalah pengambil keputusan tunggal, putusannya harus seadil-adilnya demi menjunjung tinggi hukum. Dalam mengambil keputusan hakim tidak boleh diintervensi oleh pihak manapun, hakim harus bersifat netral. Kebebasan kekuasaan kehakiman sering diidentikkan dengan kebebasan hakim. Pun juga keputusan pengadilan juga sering disamakan dengan keputusan hakim. Hal ini sangat sistematis mengingat negara indonesia adalah negara hukum sebagaimana dalam ketentuan Pasal 1 Ayat (3) UUD 1945. Sehingga negara selalu berdasarkan konstitusi dan undang-undang yang berasal dari nilai masyarakat Indonesia.

Hakim juga merupakan personifikasi dari lembaga peradilan di Indonesia yang menjadi corong daripada hukum untuk mengemban amanah yang berat. Dalam membuat keputusan hakim tidak saja dituntut memiliki kemampuan intelektual, akan tetapi juga memiliki moral dan integritas yang tinggi, juga mampu berkomunikasi dengan baik sehingga di hadapan masyarakat nampak akan kewibawaannya dalam menyelesaikan kasus hukum. Demi mewujudkan keadilan dan terwujudnya penegakan hukum yang optimal, maka pengadilan sebagai pilar utama penegakan hukum melalui peran hakim sebagai aktor utama dituntut untuk menjaga integritas, mengasah kepekaan nurani, dan profesionalisme dalam menjalankan tugasnya. Hakim dalam menjalankan kewenangan penegakan hukum memiliki tanggung jawab yang besar dalam memberikan putusan terhadap suatu perkara, baik terhadap para pihak yang

1 Nur Iftitah Isnantiana, "Legal Reasoning Hakim Dalam Pengambilan Putusan Perkara Di

Pengadilan,” Jurnal Islamadina 18, no. 2 (2017): 41-56, https://doi.org/10.30595/islamadina.v18i2.1920. 
berperkara (dalam hal ini manusia) dan tanggung jawabnya kepada Tuhan Yang Maha Esa. $^{2}$

Dalam melaksanakan tugasnya, seorang hakim harus memiliki penalaran yang baik dalam menelaah dan memberi pertimbangan yang cukup. Dalam hal ini diperlukan proses penalaran hukum atau disebut sebagai legal reasoning. Legal reasoning dalam hal ini adalah pencarian "reason" mengenai hukum atau pencarian dasar tentang bagaimana seorang hakim memutuskan suatu perkara/kasus hukum yang dihadapinya.

Namun, karena kurangnya pemahaman mengenai legal reasoning, tidak jarang pula putusan hakim dianggap sebagai Onvoldoende Gemotiveerd yakni putusan yang dianggap tidak sempurna. Tidak sempurnanya putusan hakim yang dimaksud adalah putusan yang tidak seksama mempertimbangkan semua faktafakta yang relevan dengan perkara yang bersangkutan. Pembahasan mengenai cacat tidaknya suatu putusan hakim harus ditinjau dari asas-asas putusan yang harus diterapkan dalam putusan. Pada hakikatnya, suatu putusan hakim harus memuat dasar alasan yang jelas dan rinci sebagaimana ditentukan dalam UU No. 48 Tahun 2009 tentang Kekuasaan Kehakiman. Secara sederhana putusan hakim meliputi irah-irah dan kepala putusan, pertimbangan, dan amar. Berdasarkan ruang lingkup tersebut, yang dipandang sebagai dasar putusan adalah pertimbangan.

Putusan yang dijatuhkan oleh hakim harus berdasarkan pertimbangan yang jelas dan cukup. Pertimbangan hakim adalah alasan-alasan penjatuhan hukum yang dilakukan oleh hakim yang dinyatakan dalam putusan hakim. Putusan yang tidak memenuhi pertimbangan yang jelas dan cukup disebut sebagai onvoldoende gemotiveerd. Hal tersebut ditegaskan dalam Pasal 50 UU No. 48 Tahun 2009 tentang Kekuasaan Kehakiman yang menegaskan bahwasanya Putusan pengadilan selain harus memuat alasan dan dasar putusan, juga memuat pasal tertentu dari peraturan perundang-undangan yang bersangkutan atau sumber hukum tak tertulis yang dijadikan dasar untuk mengadili.

Putusan Majelis Hakim yang tidak lengkap atau onvoldoende gemotiveerd dapat dijadikan sebagai alasan permohonan kasasi karena judex factie terbukti tidak memenuhi syarat materiil Pasal 50 Jo. Pasal 53 ayat 2 Undang-undang Nomor 48 Tahun 2009 tentang Kekuasaan Kehakiman Jo. Pasal 68 A ayat 2 Undang-Undang Nomor 49 Tahun 2009 tentang Peradilan Umum. ${ }^{3}$

Berdasarkan uraian mengenai urgensi putusan hukum yang baik agar tidak termasuk sebagai onvoldoende gemotiveerd dan konsekuensi yang diakibatkan

2 Jimly. Asshidiqie, Peradilan Etika Dan Etika Konstitusi (Jakarta: Sinar Grafika, 2014).

3 Teresia Mira PW and Harjono, "Studi Tentang Pertimbangan Hakim yang Tidak Lengkap (Onvoldoende Gemotiveerd) Sebagai Alasan Permohonan Kasasi Sengketa Sarang Burung Walet (Studi Putusan Mahkamah Agung Nomor:1609 K/Pdt/2012)," Jurnal Verstek 9, no. 2 (2021): 399-406. 
dari putusan tersebut, maka artikel ini disusun untuk memberikan dasar pemahaman mengenai pentingnya legal reasoning bagi hakim sehingga pertimbangan hakim dalam putusan dapat dinyatakan telah memadai untuk menjadi dasar amar putusan yang dijatuhkan.

Dalam penelusuran literatur, terdapat beberapa penulis sebelumnya yang mengangkat tema mengenai urgensi legal reasoning dalam putusan hakim pada berbagai jurnal ilmiah, diantaranya adalah: Pertama, Juanda (2017) yang menulis artikel berjudul "Penalaran Hukum (Legal Reasoning)", kedua, Isnantiana (2017) dengan judul "Legal Reasoning Hakim dalam Pengambilan Putusan Perkara di Pengadilan”, ketiga, Taqiuddin (2017)dengan judul "Penalaran Hukum (Legal Reasoning) dalam Putusan Hakim”. Ketiga artikel tersebut mengangkat relasi legal reasoning dalam putusan hakim secara umum. Sementara itu, artikel ini memiliki kebaruan dalam hal kekhususan pembahasan mengenai relasi legal reasoning untuk menghindari onvoldoende gemotiveerd. Suatu putusan hakim harus memuat legal reasoning yang baik, oleh karena itu pemahaman mengenai legal reasoning bagi hakim menjadi mutlak harus dimiliki. Tulisan ini membahas mengenai bagaimana suatu putusan dapat dikategorikan sebagai Onvoldoende Gemotiveerd sehingga pertimbangan hakim yang memadai dalam suatu putusan sangat membutuhkan legal reasoning yang baik.

\section{B. Permasalahan}

Dalam penulisan artikel ini, ada dua permasalahan yang diajukan dan dibahas: Pertama, apakah hakikat legal reasoning sebagai pemandu bagi hakim dalam menjatuhkan putusan sehingga terhindar dari Onvoldoende Gemotiveerd; kedua, bagaimanakah suatu putusan hakim disebut Onvoldoende Gemotiveerd?

\section{HASIL DAN PEMBAHASAN}

\section{A. Legal Reasoning sebagai Pemandu bagi Hakim dalam Menjatuhkan Putusan}

Hakim berperan sangat penting dalam menyelesaikan permasalahanpermasalahan hukum yang terjadi di masyarakat, khususnya yang diselesaikan di jalur hukum melalui proses persidangan. Hakim merupakan lambang dari lembaga peradilan yang memiliki kewenangan untuk menegakkan hukum, dengan menyelesaikan berbagai permasalahan hukum yang diajukan ke persidangan dalam bentuk putusan yang dijatuhkannya. Dengan demikian, hakim harus bisa menyelesaikan permasalahan hukum tersebut dengan menjunjung nilai-nilai kebenaran melalui paradigma yang dianutnya. Agar nilainilai tersebut dapat diwujudkan dalam penegakan hukum, sebelum hakim menjatuhkan putusan, seorang hakim harus memverifikasi fakta dan peristiwa, serta alat-alat bukti yang diajukan oleh para pihak dalam persidangan, sehingga 
ditemukan fakta atau peristiwa yang konkret yang memandu keyakinan atas kebenaran bagi hakim tersebut.

Berdasarkan Pasal 5 ayat (1) Undang-Undang Nomor 48 Tahun 2009 tentang Kekuasaan Kehakiman berbunyi "Hakim dan hakim konstitusi wajib menggali, mengikuti, dan memahami nilai-nilai hukum dan rasa keadilan yang hidup dalam masyarakat." Berdasarkan pasal penjelasannya, ketentuan ini dimaksudkan agar putusan hakim dan hakim konstitusi sesuai dengan hukum dan rasa keadilan masyarakat. Untuk itu, dalam memutus suatu perkara atau permasalahan hukum seorang hakim sebagai penegak hukum selain harus mengetahui dasar-dasar hukum apa yang akan digunakan dalam memutus perkara tersebut. Seorang hakim juga harus memahami nilai-nilai hukum yang hidup di masyarakat menggunakan penalaran dalam akal pikirannya. Penalaran merupakan usaha untuk memperoleh kebenaran dengan menggunakan nalar atau akal pikiran yang logis, penalaran ini digunakan hakim untuk berpikir secara lurus atau logis, memberikan pertimbangkan mengenai benar atau salahnya sesuatu. Nalar membantu dengan menuntut hakim untuk berpikir dan menjawab hasil pemikiran atas permasalahan hukum yang sedang dihadapi.

Penegakan hukum merupakan proses implementasi hukum secara empiris di masyarakat yang melibatkan kemampuan penegak hukum dalam memaknai hukum. Pemaknaan hukum terjadi saat penelaah hukum atau penegak hukum itu melakukan proses membangun argumentasi hukum atas realitas empiris yang terjadi. Dalam upaya membangun argumentasi hukum itu, seorang penegak hukum memerlukan penalaran hukum. ${ }^{4}$ Penalaran hukum adalah berpikir, menggunakan, mengembangkan atau mengendalikan suatu masalah di bidang hukum dengan menggunakan nalar, atau bisa disebut legal reasoning. Legal reasoning ini ialah penalaran tentang hukum yaitu pencarian "reason" tentang hukum atau pencarian dasar tentang bagaimana seorang hakim memutuskan perkara atau kasus hukum, seorang pengacara mengargumentasikan hukum dan bagaimana seorang ahli hukum menalar hukum. ${ }^{5}$ untuk itu seorang hakim harus memiliki kemampuan dan keterampilan yang baik untuk memahami penalaran hukum.

Menurut Wasis Susetio, legal reasoning adalah suatu kegiatan untuk mencari dasar hukum yang terdapat di dalam suatu peristiwa hukum, baik yang merupakan perbuatan hukum (perjanjian, transaksi perdagangan, dan sebagainya) ataupun yang merupakan kasus pelanggaran hukum (pidana,

\footnotetext{
4 Miftahul Qodri, “'Benang Merah’ Penalaran Hukum, Argumentasi Hukum Dan Penegakan Hukum," Jurnal Hukum Progresif 7, no. 2 (2019): 182, https://doi.org/10.14710/hp.7.2.182-191.

5 Ni Luh Putu Vera and Nurun Ainudin, "Logika Hukum Dan Terobosan Hukum Melalui Legal Reasoning," Jurnal Hukum Jatiswara 31, no. 1 (2016): 99-110.
} 
perdata, ataupun administratif) dan memasukkannya ke dalam peraturan hukum yang ada. ${ }^{6}$ M. Arsyad Sanusi, seorang Hakim Mahkamah Konstitusi Republik Indonesia dalam sebuah artikelnya berjudul "Legal Reasoning dalam Penafsiran Konstitusi” mengutip Golding yang menyebutkan sebagai berikut: ${ }^{7}$

“Terma 'legal reasoning' dapat digunakan dalam dua arti yaitu dalam arti luas dan sempit. Dalam arti luas, legal reasoning berkaitan dengan proses psikologis yang dilakukan hakim untuk sampai pada putusan atas kasus yang dihadapinya. Sedangkan, legal reasoning dalam arti sempit berkaitan dengan argumentasi yang melandasi suatu keputusan. Artinya legal reasoning dalam arti sempit ini menyangkut kajian logika dari suatu putusan, yaitu hubungan antara reason (pertimbangan, alasan) dan putusan, serta ketepatan alasan atau pertimbangan yang mendukung putusan tersebut".

Bentuk konkret dari penalaran hukum dapat dilihat dari silogisme (inferensi deduktif) yang bertitik tolak dari premis mayor, premis minor, dan konklusi. Kaitannya dengan profesi hakim ialah bahwa hakim merupakan profesi yang mulia (officium nobile) di mana keputusan yang dimuat oleh hakim haruslah keputusan yang berdasarkan oleh etika, moral serta penalaran hukum yang tinggi, sehingga hakim dapat memutuskan dengan seadil-adilnya demi menjunjung tinggi nilai keadilan. Hal ini wajib dimiliki dan diamalkan oleh para hakim untuk menjamin tegaknya kewibawaan dan kehormatan hakim.

Penalaran hukum sendiri berfungsi untuk sebagai wadah atau kerangka berfikir hakim dalam menentukan langkah selanjutnya. Penalaran sendiri membutuhkan suatu pola berfikir yang sangat luas secara (logis) untuk dicerna dan dipahami oleh manusia. Hal ini pun pasti menghasilkan suatu penalaran yang berbeda-beda tergantung dari pola proses berfikir setiap manusia yang dipengaruhi oleh banyak faktor termasuk faktor-faktor yang bersifat internal ataupun eksternal. Thomas Halper, menyatakan bahwa penalaran hukum tidak disukai oleh orang hukum. Persoalan hukum dianggap bukan persoalan yang logis. Logika dianggap berisikan sinyal baku dan tidak elastis tentang persoalanhukum dan konsitusi yang begitu kompleks. Maka para hakim tidak harus memahami hukum secara logis. ${ }^{8}$

Menurut Halper, sebuah persoalan dan putusan hukum tidak boleh terbatas pada makna proposisi yang hanya dianggap logis semata dengan mengabaikan konteks dan tujuan hukum. Banyak hal dalam hukum yang tidak dengan mudah

\footnotetext{
${ }^{6}$ Wasis Susetio, "Pelatihan Hukum Acara MK" (Ditjen PP Kementerian Hukum dan HAM, 2011).

7 H Enju Juanda, "Penalaran Hukum (Legal Reasoning)," Jurnal Galuh Justisi 5, no. 1 (2017): 157-67, https://doi.org/10.1515/9783112358702.

8 Urbanus Ura Weruin, "Logika, Penalaran, dan Argumentasi Hukum," Jurnal Konstitusi 14, no. 2 (2017): 374, https://doi.org/10.31078/jk1427.
} 
diubah melalui silogisme dan penyimpulan. Prinsip-prinsip hukum harus dapat dipahami dalam hal yang lebih luas. Memang harus diakui bahwa pengambilan keputusan hukum (decision-making) bukan sekedar persoalan penalaran analogi, tetapi setiap putusan hukum tetap harus dapat dinalar secara akal sehat dan logis. Namun sering juga penalaran hukum ditolak, dengan alasan karena penalaran ini tidak membumi, dan hukum harus dipelajari dari yang konkrit saja. Tentu saja, hal ini tidak bisa secara serta merta dianggap menjadi benar. ${ }^{9}$

Namun terlepas dari pro kontra tentang adanya penalaran hukum, bahwa penalaran harus diajarkan sejak dini karena hal ini berkaitan dengan praktek hukum kedepannya, seperti dalam profesi hakim. Ibarat seorang pemain sepakbola, perlunya penalaran dan skill adalah kewajiban karena apabila hanya punya sebagian atau tidak sama sekali hanya membuang tenaga tanpa menghasilkan apapun. Logika juga bisa berperan dalam pengontrol emosi, prasangka, perasaan, manusia sehingga apabila memiliki logika yang baik harapannya hakim bisa lebih baik dalam pelaksanaan, dan penerapan hukum.

Karena dengan melakukan penalaran logika, hukum tak lagi mendasarkan diri pada kepentingan dan pertimbangan lain di luar nalar dan akal sehat. Dengan mengedepankan logika, maka cara berhukum yang bias dan subjektif dapat ditekan karena lebih menjamin objektifitas. Seorang hakim yang menggunakan nalar atau logika dapat tertuntun untuk memahami peristiwa hukum secara lebih terukur dalam landasan rasionalitas. Mereka akan mengabaikan hal-hal yang abstrak yang melingkupi hukum sepanjang tidak bisa diterima secara nalar berbasis akal sehat.

Dalam melakukan penalaran, seorang hakim harus memiliki sifat analitis yang dimaksudkan sebagai suatu pencerminan dari proses berpikir yang bersandar pada suatu analisis dan kerangka berpikir tertentu, dengan logika sebagai pijakannya. Analisis sendiri sebagai kegiatan berfikir dengan suatu langkah, sehingga penalaran sendiri tidak akan berdiri sendiri melainkan berdasarkan analisis intuisi dan hal lainnya. Jika hal ini dirasa kuat maka argumen yang diungkapkan di muka pengadilan dalam rangka memberikan putusan dapat dipertanggungwabkan.

Dari hal semacam ini mengapa legal reasoning atau penalaran hukum sangat dibutuhkan oleh hakim dalam rangka memutuskan perkara di pengadilan. Dalam hal ini, seorang hakim terkadang dihadapkan dalam sebuah kekosongan hukum ketika harus menangani sebuah kasus. Kekosongan hukum dalam hal tidak ditemukannya peraturan perundang-undangan sebagai pertimbangan hukum adalah wajar. Keadilan memang tidak selalu identik dengan undangundang, karena keadilan lebih luas ketimbang undang-undang.

\footnotetext{
9 Weruin.
} 
Di dalam menghadapi kekosongan hukum, hakim harus berpegang pada asas ius curia novit, dimana hakim dianggap tahu akan hukumnya. Hakim tidak boleh menolak memeriksa, mengadili, dan memutuskan suatu perkara dengan dalih tidak ada hukumnya atau tidak lengkap hukumnya. Pasal 10 ayat (1) Undang-Undang Nomor 48 Tahun 2009 Tentang Kekuasaan Kehakiman menegaskan bahwa "Pengadilan dilarang menolak memeriksa, mengadili, dan memutus suatu perkara yang diajukan dengan dalih bahwa hukum tidak ada atau kurang jelas, melainkan wajib untuk memeriksa dan mengadili". ${ }^{10}$

Ketentuan pasal ini, mengisyaratkan kepada hakim bahwa apabila suatu peraturan perundang-undangan belum jelas atau belum mengaturnya, hakim harus bertindak berdasarkan inisiatifnya sendiri untuk menyelesaikan perkara tersebut. Dalam hal ini hakim berperan untuk menentukan apa yang merupakan hukum, sekalipun peraturan perundang-undangan tidak dapat membantunya. Tindakan hakim inilah yang dinamakan penemuan hukum. apabila ia menemukan hukum tertulis, ia wajib menggali hukum tidak tertulis untuk memutus berdasarkan hukum sebagai seorang yang bijaksana dan bertanggungjawab. Dengan demikian, hakim dapat memberikan putusan yang sesuai dengan hukum dan rasa keadilan masyarakat.

Untuk memberikan putusan yang sesuai dengan hukum dan rasa keadilan masyarakat, hakim harus juga memutuskan perkara berdasarkan suara hati nuraninya. Suara hati nurani dimaksud adalah suara hati nurani untuk kepentingan masyarakat banyak bukan untuk kepentingan diri sendiri sang hakim ataukah untuk melindungi kepentingan orang-orang tertentu yang memiliki akses kekuasaan. Dalam rangka menegakkan kebenaran, keadilan, dan kepastian hukum, maka hakim tidak boleh menjadi tawanan undang-undang (meminjam istilah Prof. Satjipto Rahardjo) dengan bertindak sebagai terompet undang- undang semata. ${ }^{11}$ Untuk itu ia harus memiliki keberanian dengan melakukan penemuan hukum (rechtvinding) yang bersifat visioner dengan melihat perkembangan masyarakat ke depan, tetapi tetap berpedoman pada kebenaran dan keadilan serta memihak dan peka terhadap nasib bangsa dan keadaan negaranya.

Sudikno Mertokusumo mengatakan apa yang dinamakan penemuan hukum lazimnya adalah proses pembentukan hukum oleh hakim atau petugas-petugas hukum lainnya yang diberi tugas untuk melaksanakan hukum atau menetapkan peraturan hukum umum terhadap peristiwa hukum yang konkret. Lebih lanjut dikatakan bahwa penemuan hukum

10 Yudha Bhakti Ardhiwisastra, Penafsiran Dan Konstruksi Hukum (Bandung: Alumni, 2008).

11 Galang Asmara, "Legal Reasoning (Penalaran Hukum)" (2010). 
merupakan konkretisasi dan individualisasi peraturan (das sollen) yang bersifat umum dengan mengingat akan peristiwa konret (das sein) tertentu. ${ }^{12}$

Paul Scholten menyatakan yang dimaksud dengan penemuan hukum adalah sesuatu yang lain daripada hanya penerapan peraturan pada peristiwanya. Kadang-kadang dan bahkan sangat sering terjadi bahwa peraturannya harus ditemukan, baik dengan jalan interpretasi maupun dengan jalan analogi ataupun rechtsverfijning (penghalusan/pengkonkretan hukum). Sedangkan D.H.M. Meuwissen berpendapat mengatakan penemuan hukum ihwalnya adalah berkenaan dengan konkretisasi produk pembentukan hukum. Penemuan hukum adalah proses kegiatan pengambilan yuridik konkret yang secara langsung menimbulkan akibat hukum bagi situasi individual (putusan-putusan hakim, ketetapan, pembuatan akta oleh notaris, dan sebagainya. Dengan demikian dalam penemuan hukum yang penting adalah bagaimana mencarikan atau menemukan hukumnya untuk peristiwa konkret (in-concreto). ${ }^{13}$

Dalam rangka menemukan hukum, Pasal 5 ayat (1) UndangUndang Nomor 48 Tahun 2009 tentang Kekuasaan Kehakiman menentukan, bahwa "Hakim dan hakim konstitusi wajib menggali, mengikuti, dan memahami nilai-nilai hukum dan rasa keadilan yang hidup dalam masyarakat". Adapun dalam penjelasan pasal tersebut menyatakan, bahwa "Ketentuan ini dimaksudkan agar putusan hakim dan hakim konstitusi sesuai dengan hukum dan rasa keadilan masyarakat". Dengan demikian ketentuan tersebut memberi makna hakim merupakan perumus dan penggali nilai-nilai hidup dalam masyarakat, ia seharusnya dapat mengenal, merasakan, dan mampu menyelami perasaan hukum dan rasa keadilan yang hidup dalam masyarakat.

Untuk dapat menemukan hukum, hakim dalam memeriksa dan memutus suatu perkara menggunakan metode penemuan hukum. Metode penemuan hukum yang dianut dewasa ini, seperti yang dikemukakan antara lain oleh J.J.H. Bruggink meliputi metode interpretasi (interpretation methoden) dan konstruksi hukum ini terdiri atas nalar analogi yang gandengannya (spiegelbeeld) a contrario, dan ditambah bentuk ketiga oleh Paul Scholten penghalusan hukum (rechtsverfijning) yang dalam bahasa Indonesia oleh Soedikno Mertokusumo disebut penyempitan hukum.

Menurut Achmad Ali, ada 2 (dua) teori penemuan hukum yang dapat dilakukan oleh hakim dalam praktik peradilan, yaitu melalui metode interpretasi atau penafsiran hukum dan metode konstruksi hukum. Ada perbedaan pandangan tentang metode atau cara penemuan hukum oleh hakim menurut yuris dari Eropa Kontinental dengan yuris yang berasal dari Anglo Saxon. Pada

\footnotetext{
12 Sudikno Mertokusumo, Penemuan Hukum Suatu Pengantar (Yogyakarta: Liberty, 2009).

13 Sudikno Mertokusumo and A. Pitlo, Bab-Bab Tentang Penemuan Hukum (Jakarta: PT. Citra Aditya Bakti, 1993).
} 
umumnya yuris Eropa Kontinental tidak memisahkan secara tegas antara metode interpretasi hukum dengan metode konstruksi hukum. Hal ini dapat dilihat dalam paparan buku-buku Paul Scholten, Pitlo, Sudikno Mertokusumo, dan Yudha Bhakti Adiwisastra. Sebaliknya, para penulis yang condong ke sistem Anglo Saxon, seperti Curzon, B. Arief Shidharta, dan Achmad Ali membuat pemisahan secara tegas antara metode interpretasi hukum dan metode konstruksi hukum.

Secara umum ada 11 (sebelas) macam metode interpretasi hukum antara lain sebagai berikut: ${ }^{14}$

a. Interpretasi gramatikal, yaitu menafsirkan kata-kata dalam undang-undang sesuai kaidah bahasa dan kaidah hukum tata bahasa;

b. Interpretasi historis, yaitu mencari maksud dari peraturan perundangundangan itu seperti apa yang dilihat oleh pembuat undang-undang itu dibentuk dulu;

c. Interpretasi sistematis, yaitu metode yang menafsirkan undang-undang sebagai bagian dari keseluruhan sistem perundang- undangan, artinya tidak satu pun dari peraturan perundang-undangan tersebut dapat ditafsirkan seakan-akan berdiri sendiri, tetapi harus selalu dipahami dalam kaitannya dengan jenis peraturan lainnya;

d. Interpretasi teleologis/sosiologis, yaitu pemaknaan suatu aturan hukum yang ditafsirkan berdasarkan tujuan pembuatan aturan hukum tersebut dan apa yang ingin dicapai dalam masyarakat;

e. Interpertasi komparatif merupakan metode penafsiran dengan jalan memperbandingkan antara berbagai sistem hukum. Dengan memperbandingkan hendak dicari kejelasan mengenai makna suatu ketentuan peraturan perundang- undangan;

f. Interpretasi futuristik/antisipatif merupakan metode penemuan hukum yang bersifat antisipasi yang menjelaskan undang-undang yang berlaku sekarang (ius constitutum) dengan berpedoman pada undang-undang yang belum mempunyai kekuatan hukum (ius constituendum);

g. Interpretasi restriktif, yaitu metode penafsiran yang sifatnya membatasi atau mempersempit makna dari suatu aturan;

h. Interpretasi ekstensif, yaitu metode interpretasi yang membuat interpretasi melebihi batas-batas yang biasa dilakukan melalui interpretasi gramatikal;

i. Interpretasi autentik, yakni dimana hakim tidak diperkenankan melalukan penafsiran dengan cara lain selain dari apa yang ditentukan pengertiannya di dalam undang- undang itu sendiri;

${ }^{14}$ Sudikno Mertokusumo, Mengenal Hukum Suatu Pengantar (Yogyakarta: Liberty, 2002). 
j. Interpretasi interdisipliner, yakni dimana hakim akan melakukan penafsiran yang disandarkan pada harmoni-sasi logika yang bersumber pada asas-asas hukum lebih dari satu cabang kekhususan dalam disiplin ilmu hukum;

k. Interpretasi multidisipliner, yakni dimana hakim mem-butuhkan verifikasi dan bantuan dari disiplin ilmu lain untuk menjatuhkan suatu putusan yang seadil- adinya serta memberikan kepastian bagi para pencari keadilan.

Dalam metode konstruksi hukum ada 4 (empat) metode yang digunakan oleh hakim pada saat melakukan penemuan hukum, yaitu: ${ }^{15}$

a. Argumentum Per Analogiam (analogi) merupakan metode penemuan hukum dimana hakim mencari esensi yang lebih umum dari sebuah peristiwa hukum atau perbuatan hukum yang baik yang telah diatur oleh undang-undang maupun yang belum ada peraturan nya;

b. Argumentum a Contrario, yaitu dimana hakim melakukan penemuan hukum dengan pertimbangan bahwa apabila undang-undang menetapkan hal-hal tertentu untuk peristiwa tertentu, berarti peraturan itu terbatas pada peristiwa tertentu itu dan bagi peristiwa di luarnya berlaku kebalikannya;

c. Penyempitan/Pengkonkretan hukum (rechtsverfijning) bertujuan untuk mengkonkretkan/menyempitkan suatu aturan hukum yang terlalu abstrak, pasif, serta sangat umum agar dapat diterapkan terhadap suatu peristiwa tertentu;

d. Fiksi hukum merupakan metode penemuan hukum yang mengemukakan fakta-fakta baru, sehingga tampil suatu personifikasi yang baru di hadapan kita.

Metode penemuan hukum sebagaimana diuraikan merupakan bentuk penalaran hukum hakim dalam konteks membuat suatu putusan hukum yang belum jelas atau belum ada dasar hukumnya. Hal ini merupakan suatu bentuk kemampuan penalaran hukum yang juga harus dimiliki oleh seorang hakim. Hakim selain memberikan dasar pertimbangan yang baik dalam putusan yang dijatuhkannya, juga harus mampu menentukan dasar hukum yang tepat dalam putusannya.

\section{B. "Onvoldoende Gemotiveerd" dalam Putusan Pengadilan}

Kata Onvoldoende Gemotiveerd berasal dari bahasa Belanda yang berartikan suatu keputusan yang berasal baik pengadilan tinggi maupun pengadilan negeri dalam mempertimbangkan suatu pertimbangan jauh dari dasarnya atau tidak mempertimbangkan dengan jelas tentang hal yang dikabulkan dalam amar putusannya. Juga dapat diartikan sebagai putusan yang tidak sempurna. Dalam bahasa Inggris disebut sebagai insufficient judgement.

15 Ahmad Rifai, Penemuan Hukum Oleh Hakim Dalam Persfektif Hukum Progresif (Jakarta: Sinar Grafika, 2011). 
Onvoldoende Gemotiveerd ini muncul karena adanya keputusan hakim dari pengadilan tingkat pertama/pengadilan negeri atau pengadilan tingkat kedua/ pengadilan tinggi yang memutuskan dengan Judex Facti dirasa tidak cukup dan tidak seksama dalam memberikan pertimbangan hukumnya dalam putusannya. Sehingga putusannya pun tidak sempurna. Juga bisa terjadi karena hakim tingkat negeri ataupun tingkat tinggi sendiri tidak memeriksa, meneliti serta memahami secara seksama putusan terhadap fakta hukum yang terjadi dalam persidangan di tingkat negeri ataupun tingkat tinggi. Juga bisa terjadi karena adanya diktum putusan yang saling bertentangan, dan bisa pula karena hakim menyamakan suatu makna atau menginterpretasikan suatu kata atau kalimat yang sebenarnya berbeda makna dan perbedaan makna tersebut juga memiliki aturan hukum yang juga jelas berbeda.

Akibat daripada putusan yang tidak sempurna ini adalah harus dilakukan pembatalan putusan. Hal ini pun sesuai dengan Yurisprudensi Mahkamah Agung Republik Indonesia pada Tanggal 4 Juli 1961 Nomor 384/K/SIP/1961 yang menyatakan bahwa Putusan Pengadilan tinggi dapat dibatalkan apabila tidak disertai dengan alasan yang cukup. Selain itu dalam Putusan Mahkamah Agung RI Nomor 638 K/Sip/1969 pada tanggal 22 Juni 1970 juga menegaskan putusanputusan dari pengadilan negeri dan pengadilan tinggi yang tidak lengkap atau kurang cukup untuk ditimbangkan menjadi alasan untuk kasasi dan putusan demikian harus dibatalkan. ${ }^{16}$ Juga dalam Putusan Mahkamah Agung No. 67 k/Sip/1972 yang mengandung kaidah hukum "putusan Judex factie yang harus dibatalkan jika Judex factie tidak memberikan alasan atau pertimbangan yang cukup dalam hal dalil-dalil tidak bertentangan dengan pertimbanganpertimbangan". 17

Namun, Onvoldoende Gemotiveerd ini terkadang juga berasal dari ketidakjelasan pemohon akan suatu perkara di mana dalam studi kasus putusan Pengadilan Tinggi Surabaya pada 23 Juli 1986 No. 393/Pdt/1986/PT.sby di mana kasusnya mengenai jual beli yang dibayar dengan giro kosong. ${ }^{18}$ Dalam kasusnya pemohon tidak jelas dalam memberikan pernyataan. Dalam pernyataannya di pengadilan negeri menyatakan sebagai pembeli sedangkan pemohon menyatakan pernyataan berbeda di pengadilan tinggi yakni menyatakan sebagai peminjam, adanya ketidakjelasan diktum semacam ini ketika hakim dibawakan dalam kenyataan seperti ini harusnya ditolak atau batal demi hukum, karena dapat menyebabkan suatu kesimpangsiuran yang dapat

16 "Yurisprudensi Putusan Mahkamah Agung No. 3115/K/Pdt/2015" (Jakarta, 2015).

17 Mys, "Bahasa Hukum: Onvoldoende Gemotiveerd," hukum Online, 2021, https://www.hukumonline.com/berita/baca/lt4eba3e97b3807/bahasa-hukum-onvoldoendegemotiveerd $/$ ?page $=2$.

18 “Putusan Pengadilan Tinggi Surabaya No. 393/Pdt/1986/PT.Sby" (Surabaya, 1986). 
menyesatkan semua orang termasuk hakim dalam memberikan putusannya. Keputusan yang dilakukan hakim di Pengadilan Tinggi Surabaya pun malah melanjutkan perkara ini sehingga sudah dapat dipastikan putusannya sesat atau tidak sempurnya Onvoldoende Gemotiveerd.

Oleh karena itu wajib hukumnya bagi hakim untuk mengetahui segala hal yang berkaitan dengan hukum. Ius Curia Novit/Curia Novit Jus berarti hakim dianggap mengetahui semua hukum sehingga Pengadilan tidak boleh menolak memeriksa dan mengadili perkara. ${ }^{19}$ Walaupun tidak melepas kemungkinan bahwa kesalahan ada pada pemohon saat mengajukan perkara di pengadilan, juga pada dasarnya hakim yang juga manusia yang dapat berbuat salah/keliru dalam memutuskan suatu perkara. Namun secara mendasar, hakim wajib memiliki kemampuan untuk melakukan menemukan hukum, penalaran hukum hakim berdasar dari kemampuannya berpikir untuk menginterpretasikan hukum yang diimplementasikan dalam kasus yang ditanganinya dengan menggunakan metode konstruksi hukum, sehingga ketika hakim memiliki kemampuan penalaran hukum yang baik dapat meminimalisir terjadinya salah tafsir dan semacamnya yang kemudian dapat menyebabkan sesat atau tidak sempurnanya suatu putusan di pengadilan. Hal ini juga akan memberikan memberikan dasar pertimbangan yang baik dalam putusan yang dijatuhkannya.

Pola pemikiran ini sangat penting dimiliki oleh hakim karena adanya kesesatan dalam berpikir dapat menyebabkan keresahan di dalam masyarakat tatkala keputusan hakim dianggap tidak memuaskan dan terkesan menciderai hukum itu sendiri. Maka dari itu adanya penalaran hukum dapat membantu hakim dalam membuat keputusan lebih adil dan sesuai dengan hukum, norma serta penalaran yang baik dan benar. Terlebih apabila suatu peristiwa hukum yang tidak terdapat pengaturannya dalam perundang-undahgan sehingga adanya kekosongan ini terkadang ada pengaturannya namun tidak jelas sehingga membutuhkan konstruksi hukum sebagai cara mengisi kekosongan peraturan perundang-undangan. Di dalam praktik pengadilan sendiri, untuk menemukan atau mencari hukum tidak hanya sekedar mencari undang-undangnya untuk diterapkan pada peristiwa yang sedang diadilinya. Namun, untuk menemukan hukumnya peristiwa konkret diharuskan untuk diarahkan pada regulasi yang ada agar dapat diterapkan pada perstiwa yang konkret, sedangkan undang-undang sendiri harus disesuaikan dengan peristiwanya agar saling meliputi antara regulasi dan peristiwa yang terjadi. ${ }^{20}$

\footnotetext{
19 Yahya Harahap, Hukum Acara Perdata Tentang Gugatan, Persidangan, Penyitaan, Pembuktian Dan Putusan Pengadilan (Jakarta: Sinar grafika, 2016).

${ }_{20}$ Sudikno Mertokusumo, Hukum Acara Perdata Indonesia, 5th ed. (Yogyakarta: Universitas Atmajaya, 2010).
} 
Setelah dilakukan penemuan hukum dengan didasari pola pikir yang baik yang dimiliki hakim maka peristiwa yang sebelumnya berupa peristiwa yang konkret menjadikannya peristiwa hukum. Penerapan daripada regulasi dengan peristiwa yang ada ini bagaikan menerapkan silogisme dimana yang diilustrasikan sebagai "siapa yang membunuh maka akan dihukum penjara" (Pasal 338 KUHP), kemudian dalam peristiwa konkretnya "si A membunuh temannya karena dendam", maka simpulan yang dapat diambil adalah "si A harus dihukum karena membunuh temannya dengan melawan hukum". ${ }^{21}$ Oleh karena itu, hasil akhir penafsiran hukum harus logika atau masuk akal atau "ketemu nalar". Artinya, hasil penafsiran tersebut dapat diterima oleh logika berpikir dari seluruh pihak. Hasil penafsiran hukum adalah masuk akal apabila penafsiran hukum tersebut sesuai dengan harapan atau ekspektasi semua pihak dalam nalar yang diterima dengan prinsip generalisasi.

\section{PENUTUP}

Berdasarkan uraian dalam pembahasan dapat ditarik simpulan bahwa penalaran hukum (legal reasoning) adalah hal yang sangat dibutuhkan penegak hukum khususnya hakim dalam menyelesaikan suatu perkara di persidangan. Penalaran juga membantu hakim dalam melakukan penemuan hukum, dimana penemuan hukum merupakan bagian dari penalaran hukum seorang hakim. Bentuk penalarannya di dalam praktek pengadilan sendiri, untuk menemukan atau mencari hukum tidak hanya sekedar mendari undang-undangnya untuk diterapkan pada peristiwa yang sedang diadilinya Melainkan untuk menemukan hukumnya peristiwa kongret diharuskan untuk diarahkan pada regulasi yang ada agar dapat diterapkan pada perstiwa yang kongkret, sedangkan undang-undang sendiri harus disesuaikan dengan peristiwanya agar saling meliputi antara regulasi dan peristiwa yang terjadi.Untuk itu dibutuhkan pemahaman yang baik mengenai penalaran hukum ini oleh para penegak hukum, karena akan mempermudah penegak hukum terutama hakim untuk menetapkan sebuah keputusan yang memberi rasa keadilan, kemanfaatan dan kepastian hukum yang dapat diterima secara nalar bagi para pihak dan masyarakat, sehingga dapat disimpulkan bahwa penalaran hukum ini sangat berperan penting dalam setiap pengambilan keputusan oleh hakim. Dengan bekal penalaran hukum yang dimilikinya, hakim sudah bisa menghadapi segala permasalahan yang ada, sehingga dapat memberikan dasar pertimbangan yang cukup dan menghindari Onvoldoende Gemotiveerd dalam putusan yang dijatuhkannya di pengadilan tingkat satu dan pengadilan tingkat tinggi.

\footnotetext{
21 Mertokusumo.
} 


\section{DAFTAR PUSTAKA}

Ardhiwisastra, Yudha Bhakti. Penafsiran Dan Konstruksi Hukum. Bandung: Alumni, 2008.

Asmara, Galang. "Legal Reasoning (Penalaran Hukum)." 2010.

Asshidiqie, Jimly. Peradilan Etika Dan Etika Konstitusi. Jakarta: Sinar Grafika, 2014.

Harahap, Yahya. Hukum Acara Perdata Tentang Gugatan, Persidangan, Penyitaan, Pembuktian Dan Putusan Pengadilan. Jakarta: Sinar grafika, 2016.

Juanda, H Enju. "Penalaran Hukum (Legal Reasoning)." Jurnal Galuh Justisi 5, no. 1 (2017): 157-67. https://doi.org/10.1515/9783112358702.

Mertokusumo, Sudikno. Hukum Acara Perdata Indonesia. 5th ed. Yogyakarta: Universitas Atmajaya, 2010.

—. Mengenal Hukum Suatu Pengantar. Yogyakarta: Liberty, 2002.

—. Penemuan Hukum Suatu Pengantar. Yogyakarta: Liberty, 2009.

Mertokusumo, Sudikno, and A. Pitlo. Bab-Bab Tentang Penemuan Hukum. Jakarta: PT. Citra Aditya Bakti, 1993.

Mys. "Bahasa Hukum: Onvoldoende Gemotiveerd." hukum Online, 2021. https://www.hukumonline.com/berita/baca/lt4eba3e97b3807/bahasahukum-onvoldoende-gemotiveerd/?page $=2$.

Ni Luh Putu Vera, and Nurun Ainudin. "Logika Hukum Dan Terobosan Hukum Melalui Legal Reasoning.” Jurnal Hukum Jatiswara 31, no. 1 (2016): 99110.

Nur Iftitah Isnantiana. "Legal Reasoning Hakim Dalam Pengambilan Putusan Perkara Di Pengadilan." Jurnal Islamadina 18, no. 2 (2017): 41-56. https://doi.org/10.30595/islamadina.v18i2.1920.

"Putusan Pengadilan Tinggi Surabaya No. 393/Pdt/1986/PT.Sby." Surabaya, 1986.

Qodri, Miftahul. “'Benang Merah' Penalaran Hukum, Argumentasi Hukum Dan Penegakan Hukum.” Jurnal Hukum Progresif 7, no. 2 (2019): 182. https://doi.org/10.14710/hp.7.2.182-191.

Rifai, Ahmad. Penemuan Hukum Oleh Hakim Dalam Persfektif Hukum Progresif. Jakarta: Sinar Grafika, 2011.

Susetio, Wasis. "Pelatihan Hukum Acara MK." 2011.

Teresia Mira PW, and Harjono. "Studi Tentang Pertimbangan Hakim Yang Tidak Lengkap (Onvoldoende Gemotiveerd) Sebagai Alasan Permohonan Kasasi Sengketa Sarang Burung Walet (Studi Putusan Mahkamah Agung Nomor:1609 K/Pdt/2012)." Jurnal Verstek 9, no. 2 (2021): 399-406.

Weruin, Urbanus Ura. "Logika, Penalaran, Dan Argumentasi Hukum.” Jurnal Konstitusi 14, no. 2 (2017): 374. https://doi.org/10.31078/jk1427.

"Yurisprudensi Putusan Mahkamah Agung No. 3115/K/Pdt/2015." Jakarta, 2015. 